\title{
Soju brewing characteristics of yeast strains N4 and N9 isolated from Korean traditional Nuruk
}

\author{
Han-Seok Choi*, Ji-Eun Kang, Seok-Tae Jeong, Chan-Woo Kim, \\ Seong-Yeol Baek, Soo-Hwan Yeo \\ Fermented Food Science Division, National Institute of Agricultural Sciences, RDA, Wanju 55365, Korea
}

\section{재래누룩에서 분리한 N4와 N9 효모의 증류식 소주 양조특성}

\author{
최한석*·강지은 · 정석태·김찬우·백성열·여수환 \\ 농촌진흥청 국립농업과학원 발효식품과
}

\begin{abstract}
Soju is a Korean traditional distilled alcoholic beverage produced from mashes various crops and Nuruk which is cultured with wild microorganisms. This study was conducted to investigate rice-Soju brewing characteristics of yeasts isolated from Korean traditional Nuruk. The general components of rice (Hanarumbyeo) raw materials were $14.7 \mathrm{~g}$ of water, $6.8 \mathrm{~g}$ of crude protein, $0.9 \mathrm{~g}$ of crude lipid, $0.4 \mathrm{~g}$ of crude ash, and $76.5 \mathrm{~g}$ of carbohydrate in $100 \mathrm{~g}$. Saccharifying and proteolytic activities in Hanarumbyeo ipguk (solid-state culture of Aspergillus luchuensis) were also determined. The alcohol content of the fermented wash from isolates was $15.37-16.58 \%$ (v/v), which is $16.7-36.0 \%$ higher than that of industrial yeasts $(12.33-13.19 \%)$. Reducing sugar contents were $2.04-3.92$ and 7.92-8.78 $\mathrm{g} / 100 \mathrm{~mL}$ in the isolates and industrial yeasts, respectively. The isolated yeasts showed 25.2-52.7\% higher yield of distillates $(41 \%$ alcohol) compared to industrial yeasts. Forty-one components were detected in the rice distillated Soju ( $25 \%$ alcohol) and principal component analysis revealed differences between the isolated and industrial yeasts with respect to the contents of $\mathrm{i}-\mathrm{BuOH}$, isobutanal diethyl acetal, ethyl caprate, and tetradecanoic acid.
\end{abstract}

Key words : Nuruk, Soju, Saccharomyces cerevisiae N4, Saccharomyces cerevisiae N9, brewing characteristics

\section{서 론}

인류가 농경을 시작하면서 각 문명은 자연스럽게 그 지 역에서 얻기 쉬운 농작물로 술을 만들기 시작하였다. 메소 포타미아와 이집트에서는 보리를 싹 틔워 쓰거나 포도, 사 과 등을 이용하였고 잉카는 옥수수나 사탕수수를 사용하였 다(1). 반면 한국, 중국, 일본, 인도네시아, 인도, 네팔 등 아시아권에서는 쌀과 잡곡에 누룩을 첨가하는 양조법으로 발전되어 왔다(2). 발효주에 증류기술이 적용되면서 위스 키, 브랜디, 꼬냑, 럼, 보드카 등의 다양한 증류주가 만들어

*Corresponding author. E-mail : coldstone@korea.kr Phone : 82-63-238-3639, Fax : 82-63-238-3843

Received 8 August 2017; Revised 20 August 2017; Accepted 23 August 2017.

Copyright (c) The Korean Society of Food Preservation. All rights reserved.
지기 시작하였고 우리나라와 중국, 일본은 각각 소주(燒酒), 백주(向酒, báijiü), 쇼추(燒酎, shochu)로 분류하였으며(2) 현재까지도 널리 음용되고 있다.

우리나라의 주류시장에서 소주가 차지하는 비중은 2015 년 출고금액기준, 희석식 소주가 3 조 4,666억 원으로 전체 주류의 $37 \%$ 를 차지하고 있으나 증류식 소주는 195 억 원으 로 $0.21 \%$ 에 불과하다(3). 우리나라에서 증류식 소주가 쇠퇴 한 이유는 일제강점기 시대 주세법에 따른 다양성의 축소와 한국전쟁으로 경제가 어려워지면서 값싼 술을 찾을 수밖에 없었던 역사적 배경을 들 수 있다. 이외에 쌀을 주류제조에 사용하지 못하게 하는 양곡관리법 등의 조치가 이어지면서 1976년 증류식 소주 제조장은 국내에서 완전히 사라지게 되고 희석식 소주는 꾸준히 성장하게 된다(4). 이후 1990년 쌀 사용이 허용되면서 증류식 소주도 다시 생산되기 시작하 였고 2015년 국내에 55개 제조장이 운영 중이다 $(4,5)$.

그러나 제품경쟁력이 외국산 증류주에 밀리면서 2015년 
$31,402 \mathrm{~kL}(2,683$ 억원)의 증류주가 수입되었다(6). 2015년 국내 증류식 소주 생산량이 $954 \mathrm{~kL}(6)$ 이므로 국내생산량의 33 배가량이 수입되었다. 주류의 수입은 단순히 무역수지 악화로 끝나는 문제가 아니라 주류를 만드는 농산물을 포함 한 일자리 및 문화 등이 국내에 유입되는 의미도 가지고 있다. $1 \mathrm{~L}$ 의 위스키를 생산하는데 약 $1.13 \mathrm{~kg}$ 의 곡물이 사용 되므로(7) 2015년 수입된 $16,963 \mathrm{~kL}$ (6)의 위스키는 술과 더불어 2 만톤의 보리가 국내로 유입된 것이다.

이러한 문제를 극복하기 위해서는 다양한 노력이 필요하 겠지만 품질경쟁력 확보가 시급한 문제로 판단된다. 증류 주 제조에 필요한 기술은 원료처리, 누룩제조, 발효, 증류, 숙성, 폐수처리 및 기계설비 제작기술 등을 꼽을 수 있다. 현재까지의 연구를 살펴보면, 원료영역에 있어서는 쌀(8), 고구마(9), 감자(10), 잡곡(11) 등이 소재로 이용되었고, 누 룩제조 분야에서는 누룩 미생물의 분포 및 특성(12-14), 제 조법 최적화(15) 등의 연구가 있고, 발효기술연구로는 누룩 과 국균의 종류에 따른 특성의 변화(16,17), 가수량(18), 미 생물 혼합배양(19), 유기산 첨가(20) 등이 시도되었다. 증류 분야에서는 유기산 에스테르화(21) 및 증류방법에 따른 품 질변화 조사(22) 등이 있으며 숙성, 폐수처리, 기계설비에 대한 연구는 찾아보기 어려운 실정이다. 증류식 소주의 품 질을 높이기 위해서는 보다 근본적이고 제조현장에 부합한 체계적인 연구가 시급하다.

우리나라와 일본의 증류식 소주는 산 생성이 높은 백국 균(Aspergillus luchuensis)을 사용하기 때문에(23) 산도가 높은 환경에서 안정적인 발효를 할 수 있는 효모가 필요하 다. 그러나 국내에서는 증류식 소주용 효모가 판매되고 있 지 않기 때문에 많은 양조장에서 막걸리용 효모나 수입 빵효모를 사용하고 있는 실정이다. 본 연구팀은 국내 10 개 지역에서 수집한 누룩으로부터 내산성이 높은 효모 2종을 분리하였고(24,25) 증류식 소주 제조특성에 대하여 조사하 였기에 보고하는 바이다.

\section{재료 및 방법}

\section{공시재료}

효모는 재래누룩에서 분리한 N4(KACC93224P), N9 (KACC93234P) 및 국내 증류식 소주 양조장에서 사용되고 있는 효모를 사용하였다. 건조효모는 (쥐충무발효(Ulsan, Korea)에서 생산하고 있는 충무 종효모(CM)와 빵효모(La Parisienne, S.I. Leasaffre Co., Marcq-en-Baroeul, France; LP) 를 구매한 후 순수 분리한 다음 사용하였다. 대조구로는 일본의 증류식 소주용 효모 C4(26)를 사용하였다. 종국은 (주충무발효의 백국을 사용하였다. 쌀은 한아름 품종을 시중 에서 구입하여 이용하였다.

\section{전배양}

전배양은 YPD 배지(Difco-BD, Sparks, MD, USA)에서 수행하였다. 삼각플라스크에 배지 $10 \mathrm{~mL}$ 를 분주하고 1 백 금이를 접종한 뒤 $30^{\circ} \mathrm{C}, 150 \mathrm{rpm}$ 에서 24 시간 배양하였다.

\section{입국제조}

쌀 $3 \mathrm{~kg}$ 을 세척시간을 합쳐 60 분간 수침하고 60 분간 물빼 기 한 뒤 60 분간 증자하였다. 증자미를 $40^{\circ} \mathrm{C}$ 까지 냉각시키 고 종국 $0.3 \mathrm{~g}$ 을 접종한 다음 제국기(Mini-15, Yaegaki Food Co., Hyogo, Japan)에서 43시간동안 배양시켰다. 배양시간 $19,24,28$ 시간째 뒤집기를 하여 외부의 공기를 주입시키고 곰팡이가 고루 자라도록 하였으며 품온은 $38^{\circ} \mathrm{C}$ 로 유지시켰 다. 배양 28 시간 이후에는 품온을 $35^{\circ} \mathrm{C}$ 로 낮추어 산 생성이 증가되도록 하고(27) 배양 43 시간 째 회수하여 $-20^{\circ} \mathrm{C}$ 에 보 관하면서 사용하였다.

\section{술덧제조}

밑술은 물 $480 \mathrm{~mL}$ 에 효모 전배양액 $8.8 \mathrm{~mL}$ 를 넣은 다음 입국 $400 \mathrm{~g}$ 을 첨가하고 $30^{\circ} \mathrm{C}$ 수욕 상에서 5 일간 발효하여 제조하였다. 본 발효는 밑술에 백미 $800 \mathrm{~g}$ 상당량의 증자미 와 물 $1,920 \mathrm{~mL}$ 를 첨가한 다음 $30^{\circ} \mathrm{C}$ 수옥 상에서 발효시켰 다. 발효기간은 전날과의 무게 차이가 $0.5 \mathrm{~g}$ 이하로 될 때까 지 하였다. 이때 첨가된 입국과 백미의 무게는 수분 $12.5 \%$ 일 때의 무게로 제국 및 증자과정에서 흡수되는 수분량은 첨가되는 물 양에서 제외하였다. 전체적으로는 입국사용량 은 전분질 원료의 $1 / 3$, 급수비율은 $160 \%$ 모델을 사용하였 다. 발효경과는 매일 무게를 측정하여 그 변화량으로 산출 하였다.

\section{증류}

증류는 상압증류를 수행하였다. 술덧 $700 \mathrm{~g}$ 을 유리용기 에 넣고 스팀발생기에서 생성된 증기가 술덧에 직접 주입 되도록 제작된 기구를 이용하였다(28). 증류 종말점은 받아 진 증류액(원주)의 알코올 농도가 $41 \%$ 가 될 때로 하였다.

\section{쌀 일반성분}

수분은 적외선 수분측정기(MX-50, A\&D Co., Ltd., Tokyo, Japan)를 사용하였으며 조지방, 조단백질, 조회분 및 탄수화물 함량은 식품공전(29)에 준하여 실시하였다.

\section{쌀 수분흡수율}

한아름 품종 백미 $50 \mathrm{~g}$ 을 밖으로 이탈되지 않도록 거즈로 잘 감싸고 증류수가 담겨있는 $250 \mathrm{~mL}$ 비이커에 수침시킨 다음 10 분 단위로 꺼내 세게 흔들어 쌀에 붙어 있는 수분을 잘 제거한 다음 무게를 측정하였다. 수분흡수율은 원료에 대한 무게 증가율로 나타내었다. 이때 물 양은 쌀이 충분히 잠길 만큼 조절하여 실시하였다. 


\section{입국 산도 및 효소활성}

산도 측정을 위해 입국 $20 \mathrm{~g}$ 에 물 $100 \mathrm{~mL}$ 를 첨가하고 $20^{\circ} \mathrm{C}$ 에서 3시간 추출하였다. 추출물을 여과(Filter paper No. 2, Whatman International Ltd., Maidstone, England)한 뒤 10 $\mathrm{mL}$ 를 취해 $0.1 \mathrm{~N} \mathrm{NaOH}$ 로 적정하고 그 $\mathrm{mL}$ 수를 산도로 표시하였다. 효소활성 측정을 위한 조효소액은 입국 $20 \mathrm{~g}$ 에 $0.5 \% \mathrm{NaCl}$ 함유 $10 \mathrm{mM}$ acetate buffer(pH 5.0) $100 \mathrm{~mL}$ 로 추출한 뒤 여과하여 제조하였다. 추출조건과 여과조건은 산도측정용 시료 제작과 동일하게 하였다. 당화력, $a$ -amylase, gluco-amylase, a-glucosidase 및 acidic carboxypeptidase 는 양조용 효소 측정 kit(Kikkoman Co., Tokyo, Japan)를 사용하였다.

\section{당화력}

당화력은 기질인 4-nitro-phenyl- $\beta$-maltoside(G2- $\beta$-PNP) 를 4-nitro-phenyl- $\beta$-glucoside(G1- $\beta$-PNP)로 분해시키는 활 성으로 구하였다. 기질에 조효소액을 반응시킨 후 분해된 G1- $\beta$-PNP에 $\beta$-glucosidase를 작용시켜 유리된 4-nitrophenol (PNP)를 $440 \mathrm{~nm}$ 에 측정한 후 제조사가 제시하는 계산식으 로 산출하였다(30).

\section{a-Amylase}

조효소액이 2-chloro-4-nitrophenyl $6^{5}$-azido- $6^{5}$-deoxy- $\beta$ -maltopentaoside(N3-G5- $\beta-\mathrm{CNP})$ 를 2-chloro-4-nitrophenyl $\beta$-maltotrioside(G3- $\beta$-CNP)와 2-chloro-4-nitrophenyl $\beta$ -maltoside(G2- $\beta-\mathrm{CNP})$ 로 분해시키는 활성으로 하였다. 기 질용액에 조효소액을 첨가하여 반응을 개시시키고 동시에 gluco-amylase와 $\beta$-glucosidase를 첨가하여 분해생성물인 G3- $\beta$-CNP와 G2- $\beta-\mathrm{CNP}$ 로부터 2-chloro-4-nitrophenol(CNP) 를 유리시켰다. 최종 생성된 $\mathrm{CNP}$ 의 $400 \mathrm{~nm}$ 에서 정량하여 a-amylase의 활성으로 환산하였다(31).

\section{a-Glucosidase, gluco-amylase}

a-Glucosidase는 4-nitro-phenyl-a-glucoside(PNPG)에서 glucose를 분해시켜 PNP를 생성시키는 활성으로 하였고 gluco-amylase는 당화력과 a-glucosidase의 반응속도와 활 성차이로 산출하였다(32).

\section{Acidic carboxypeptidase}

Carbobenzoxy-L-tyrosyl-L-alanine(Cbz-Tyr-Ala)에서 L-alanine을 분해시키는 활성으로 측정하였다(33).

\section{$\beta$-Glucosidase}

기질용액(1 mM p-nitrophenol- $\beta$-D-glucoside/ $50 \mathrm{mM}$ sodium acetate buffer, $\mathrm{pH} 5.0) 0.5 \mathrm{~mL}$ 를 $37^{\circ} \mathrm{C}$ 에서 5 분간 예열한 후 조효소액 $50 \mu \mathrm{L}$ 를 첨가하였다. 이 후 $37^{\circ} \mathrm{C}$ 에서 10 분간 반응시킨 다음 $200 \mathrm{mM} \mathrm{Na} \mathrm{CO}_{3}$ 용액 $1 \mathrm{~mL}$ 를 첨가하여 반응
을 정지시키고 $410 \mathrm{~nm}$ 에서 흡광도를 측정하여 유리된 p-nitrophenol을 측정하였다. $\beta$-Glucosidase 활성은 PNPG에 서 $37^{\circ} \mathrm{C}, 1$ 분간에 $1 \mathrm{nmol}$ 의 p-nitrophenol을 만드는 활성을 1 unit로 하였다.

\section{술덧분석}

효모수는 methylene blue $(0.01 \% \mathrm{w} / \mathrm{v}$ methylene blue, $2 \%$ $\mathrm{w} / \mathrm{v}$ sodium citrate)로 염색한 후 현미경으로 계수하였고(34) 알코올, 산도, $\mathrm{pH}$, 휘발산도, 환원당, 총당 함량은 주류분석 규정을 따랐다(35).

\section{향기성분 분석}

증류된 알코올 농도 $41 \%$ 원주에 증류수를 첨가하여 알코 올 농도를 $25 \%$ 로 조절한 후 $4{ }^{\circ} \mathrm{C}$ 에서 3 일간 방치하여 불용 성 성분의 석출을 유도하였다. Membrane filter $(5 \mu \mathrm{m}$, Whatman International Ltd.)로 여과하여 불용성 물질을 제 거한 후 유리병에 담고 호일로 감싼 다음 $15^{\circ} \mathrm{C}$ 암소에서 1 달 동안 숙성시켜 소주를 제조하였다. 소주 $10 \mathrm{~mL}$ 와 10 $\mathrm{mg} / \mathrm{L}(25 \% \mathrm{EtOH})$ 농도로 제조된 methyl tridecanoate (internal standard) $100 \mu \mathrm{L}$ 를 vial에 넣었다. 이후 polydimethylsiloxane(PDMS)이 $0.5 \mathrm{~mm}$ 코팅된 $15 \mathrm{~mm}$ twister(Gerstel Co., Tokyo, Japan)를 넣고 실온에서 1,200 $\mathrm{rpm}$ 으로 1 시간 동안 교반시켜 twister에 향기성분이 흡착되 도록 하였다. 그런 다음 twister를 꺼내어 증류수로 세척하 여 불순물을 제거시키고 여분의 물은 종이 타올로 닦아내었 다. 가열탈착장치(GERSTEL TDS3, CIS4)에 장착한 후 흡 착된 성분을 $260^{\circ} \mathrm{C}$ 로 탈착시켰다(36). 성분분석은 $\mathrm{GC}-\mathrm{MS}$ (Agilent Technologies, Santa Clara, CA, USA)로 분석하였 다. 분리용 컬럼은 DB-WAX $(60 \mathrm{~m} \times 0.25 \mathrm{~mm}$ I.D., $0.25 \mu \mathrm{m}$ film thickness, Agilent Technologies Inc.)를 사용하였고 헬 륨을 $1.0 \mathrm{~mL} / \mathrm{min}$ 의 속도로 흘려주면서 분석하였다. 컬럼오 븐은 $40^{\circ} \mathrm{C}$ 에서 5 분 동안 유지시킨 다음 분당 $3^{\circ} \mathrm{C}$ 씩 $240^{\circ} \mathrm{C}$ 까 지 승온시켰다. 성분확인은 NIST05a MS spectral library data 및 AromaOffice(Nishikawa Keisoku Co., Ltd., Tokyo, Japan) database에 수록된 retention index를 참고하여 수행하 였다. 정량은 각 성분의 peak area값을 internal standard의 area값으로 나누어 internal standard 농도에 대한 상대농도 로 나타내었다.

\section{통계처리}

통계처리는 유의수준 $5 \%(\mathrm{p}<0.05)$ 로 설정하여 일원배치 분산분석을 하였으며 Minitab 16(Minitab Inc., State College, PA, USA) 프로그램을 사용하였다. 각 효모별 향기성분에 대한 주성분 분석은 XLSTAT(version 2014, Addinsoft, Paris, France)를 활용하였다. 


\section{결과 및 고찰}

\section{한아름 품종의 제국 특성}

한아름 품종(백미)의 일반성분은 Table 1 에 제시한 바와 같이 수분 14.7 , 조단백질 6.8 , 조지방 0.9 , 조회분 0.4 , 탄수 화물 $76.5 \mathrm{~g} / 100 \mathrm{~g}$ 으로 Park 등(37)의 조사결과와 유사하였 다. 한편 일반 멥쌀 백미의 조성은 각각 $13.4,6.4,0.4,0.4$, $79.5 \%(38)$ 로 한아름벼는 일반미에 비해 단백질, 회분, 탄수 화물의 함량은 유사하였으나 지질의 함량이 2 배 정도 높은 것으로 나타났다.

Table 1. Proximate compositions of polished (white) rice, Hanarumbyeo

\begin{tabular}{ccccc}
\hline \multicolumn{4}{c}{ Composition $(\mathrm{g} / 100 \mathrm{~g}$, fresh weight) } \\
\hline \multirow{3}{*}{ Moisture } & \multicolumn{3}{c}{ Crude } & \multirow{2}{*}{ Carbohydrate } \\
\cline { 2 - 4 } & Protein & Lipid & Ash & \\
\hline $14.7 \pm 0.1^{1)}$ & $6.8 \pm 0.1$ & $0.9 \pm 0.0$ & $0.4 \pm 0.0$ & $76.5 \pm 0.1$ \\
\hline
\end{tabular}

${ }^{1)}$ Values represent means \pm SD.

쌀의 흡수특성은 백미의 수분함량, 도정율, 품종, 수침온 도 등에 영향을 받으며, 수침시간이 짧으면 쌀 내부까지 수분이 흡수되지 않고, 장시간 수침할 경우 쌀에 있는 인(P) 이 유출되어 곰팡이 생육에 좋지 않은 영향을 미치게 되기 때문에(40) 수침시간 결정은 제국에서 중요한 요소이다.

한아름 품종의 수침시간에 따른 수분흡수율은 Fig. 1과 같다. 제국시 증자미의 적정 수분 함량은 쌀이 서로 엉겨 붙지 않으면서 곰팡이 생육에 영향을 받지 않고 효소활성을 확보할 수 있는 35-38\%로 조정하는 것이 일반적이다(39). 한아름 품종의 수침시간에 따른 수분흡수율은 10 분에 $17.5 \%$ 로 급격하게 증가한 후 20 분부터는 완만해지기 시작 하여 60 분에 $30.1 \%$ 로 최대 흡수량에 도달하였다. 수침 60 분 후 수분함량은 $33.6 \%$ 이었고 증자 후 수분함량은 $35.2 \%$

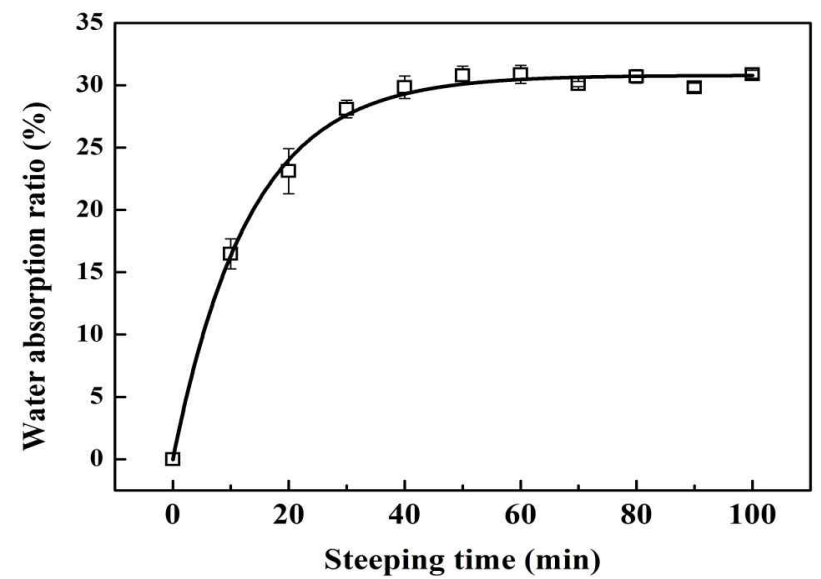

Fig. 1. Water absorption ratio of white rice, Hanarumbyeo during steeping. (data not shown)로 제국에 적절한 수분함량에 도달하였다. 따라서 한아름 품종의 적정 수침시간은 60 분이 적절할 것 으로 판단되었다.

한아름 품종으로 제조한 입국의 산도는 7.80 으로서 구연 산 함량으로 환산하면 $2.92 \mathrm{~g} / 100 \mathrm{~g}$ dry base 상당량이 함유 되어 있었다. 효소활성에 있어 당화력은 926.72, a-amylase 는 52.40, gluco-amylase는 887.71, a-glucosidase는 0.14, acidic carboxypeptidase는 17,335.73, $\beta$-glucosidase는 $174.46 \mathrm{U} / \mathrm{g}$ dry base로 조사되었다(Table 2). 일본의 소주제 조용 코지의 평균 효소활성은 a-amylase 159 , gluco-amylase 282, acidic carboxypeptidase 9,224 U/g dry base로서(41) a -amylase 활성은 3.0배 낮은 반면, gluco-amylase의 활성은 3.1배, acidic carboxypeptidase의 활성은 1.9 배 높은 것으로 나타나 일본 입국과는 차이가 있었다. 국내에서 유통되는 백국균은 수원발효에서 생산되는 SW201과 (주충무발효에 서 판매하고 있는 CF1005 두 종뿐이며 Aspergillus luchuensis(또는 $A$ luchuensis mut. kawachii)이다(42). 본 균 주는 $A$ niger의 변종으로 동아시아에 많이 분포하고 있고 산 생성능력이 높아 한국과 일본에서 증류식 소주나 막걸리 제조에 사용되어 왔으나(23), 제조사에 따라 효소활성의 차이가 있는 것으로 알려져 있다. 일본에서 유통되고 있는 8 종의 백국균을 대상으로 효소활성을 분석한 결과 최대활 성과 최소활성의 차이가 a-amylase는 2.6배, gluco-amylase 1.9 배, a-glucosidase 2.1 배, acidic carboxypeptidase 1.3 배 나 타나는 것으로 확인되었다(43). 또한 동일 제조사의 제품도 원료곡의 품종과 도정율에 따라서 효소활성의 차이가 나타 났다(44). 한국과 일본 입국의 효소활성 차이는 균주 개량 등의 영향과 품종의 차이가 복합적으로 작용되었을 가능성 이 있다.

\section{누룩분리 N4, N9효모의 발효 및 증류 특성}

발효가 완료된 술덧을 분석한 결과(Table 3) 산도는 10.95-11.70, $\mathrm{pH}$ 는 3.59-3.79 범위로 효모별로 큰 차이를 보이지 않았다. 그러나 알코올 함량은 $\mathrm{N} 9(16.58 \%)$, C4(15.98\%), N4(15.37\%), LP(13.19\%), CM(12.33\%)순으로

Table 2. Acidity and enzyme activities in Ipguk made with white rice, Hanarumbyeo

\begin{tabular}{lc}
\hline \multicolumn{1}{c}{ Component } & Value \\
\hline Acidity (0.1 N NaOH mL, fresh weight) & $7.80 \pm 0.00$ \\
Enzyme activities (U/g, ipguk dry basis) & \\
Glucose-forming & $926.72 \pm 6.07$ \\
a-Amylase & $52.40 \pm 1.30$ \\
Gluco-amylase & $887.71 \pm 5.89$ \\
a-Glucosidase & $0.14 \pm 0.00$ \\
Acidic carboxypeptidase & $17,335.73 \pm 786.50$ \\
$\beta$-Glucosidase & $174.46 \pm 4.99$ \\
\hline
\end{tabular}


Table 3. Comparison of final fermented wash by isolated and industrial yeasts

\begin{tabular}{|c|c|c|c|c|c|}
\hline & $\mathrm{N} 4$ & N9 & $\mathrm{C} 4$ & LP & $\mathrm{CM}$ \\
\hline \multicolumn{6}{|l|}{ General components } \\
\hline Alcohol (\%) & $1,5.37 \pm 0.06^{1)(2)}$ & $16.58 \pm 0.05^{\mathrm{a}}$ & $15.98 \pm 0.05^{\mathrm{b}}$ & $13.19 \pm 0.07^{\mathrm{d}}$ & $12.33 \pm 0.07^{\mathrm{e}}$ \\
\hline Acidity & $11.70 \pm 0.00^{\mathrm{b}}$ & $11.65 \pm 0.07^{\mathrm{b}}$ & $11.10 \pm 0.14^{\mathrm{c}}$ & $10.95 \pm 0.07^{\mathrm{c}}$ & $12.45 \pm 0.07^{\mathrm{a}}$ \\
\hline $\mathrm{pH}$ & $3.74 \pm 0.04^{\mathrm{ab}}$ & $3.80 \pm 0.01^{\mathrm{a}}$ & $3.67 \pm 0.03^{\mathrm{bc}}$ & $3.73 \pm 0.01^{\mathrm{ab}}$ & $3.61 \pm 0.03^{\mathrm{c}}$ \\
\hline Volatile acidity & $4.95 \pm 0.00^{\mathrm{d}}$ & $6.83 \pm 0.04^{\mathrm{a}}$ & $2.30 \pm 0.00^{\mathrm{e}}$ & $6.13 \pm 0.04^{b}$ & $5.85 \pm 0.00^{\mathrm{c}}$ \\
\hline Reducing sugar (\%) & $3.92 \pm 0.00^{\mathrm{c}}$ & $2.04 \pm 0.04^{\mathrm{e}}$ & $2.88 \pm 0.00^{\mathrm{d}}$ & $7.92 \pm 0.00^{\mathrm{b}}$ & $8.78 \pm 0.00^{\mathrm{a}}$ \\
\hline Total sugar $(\%)$ & $5.11 \pm 0.04^{\mathrm{c}}$ & $3.10 \pm 0.17^{\mathrm{e}}$ & $4.04 \pm 0.08^{\mathrm{d}}$ & $9.07 \pm 0.10^{b}$ & $9.92 \pm 0.10^{\mathrm{a}}$ \\
\hline \multicolumn{6}{|c|}{ Enzyme activities $(\mathrm{U} / \mathrm{mL})$} \\
\hline Glucose-forming & $258.39 \pm 2.62^{\mathrm{a}}$ & $253.45 \pm 0.87^{\mathrm{a}}$ & $225.32 \pm 3.06^{b}$ & $251.28 \pm 6.56^{\mathrm{a}}$ & $244.48 \pm 0.44^{\mathrm{a}}$ \\
\hline a-Amylase & $8.20 \pm 0.35^{\mathrm{bc}}$ & $7.85 \pm 0.28^{\mathrm{c}}$ & $8.74 \pm 0.14^{\mathrm{abc}}$ & $9.19 \pm 0.49^{\mathrm{ab}}$ & $9.84 \pm 0.00^{\mathrm{a}}$ \\
\hline \multicolumn{6}{|c|}{ Number of yeasts $\left(\times 10^{7}\right.$ cells $\left./ \mathrm{mL}\right)$} \\
\hline Total & $10.67 \pm 0.63^{\mathrm{a}}$ & $8.22 \pm 1.57^{\mathrm{a}}$ & $10.56 \pm 2.47^{\mathrm{a}}$ & $6.72 \pm 2.32^{\mathrm{a}}$ & $7.94 \pm 2.65^{\mathrm{a}}$ \\
\hline Live & $4.22 \pm 1.57^{\mathrm{ab}}$ & $2.22 \pm 0.63^{\mathrm{ab}}$ & $5.00 \pm 2.33^{\mathrm{a}}$ & $4.33 \pm 1.68^{\mathrm{a}}$ & $1.72 \pm 0.55^{b}$ \\
\hline Dead & $6.44 \pm 0.94^{\mathrm{ab}}$ & $6.00 \pm 2.20^{\mathrm{a}}$ & $5.56 \pm 0.26^{\mathrm{ab}}$ & $2.39 \pm 1.03^{b}$ & $6.22 \pm 2.67^{\mathrm{a}}$ \\
\hline Viability (\%) & $39.2 \pm 12.4^{\mathrm{bc}}$ & $28.3 \pm 13.0^{\mathrm{bc}}$ & $45.7 \pm 9.6^{b}$ & $64.2 \pm 9.3^{\mathrm{a}}$ & $23.7 \pm 8.7^{\mathrm{c}}$ \\
\hline \multicolumn{6}{|l|}{ Distillation } \\
\hline Distillate alcohol (\%) & $41.29 \pm 0.32^{\mathrm{a}}$ & $41.21 \pm 004^{\mathrm{a}}$ & $41.21 \pm 0.13^{\mathrm{a}}$ & $41.05 \pm 0.05^{\mathrm{a}}$ & $41.24 \pm 0.16^{\mathrm{a}}$ \\
\hline Volume (mL) & $242.23 \pm 3.91^{b}$ & $265.55 \pm 0.64^{\mathrm{c}}$ & $252.07 \pm 1.09^{\mathrm{b}}$ & $193.43 \pm 1.16^{d}$ & $173.81 \pm 1.59^{\mathrm{e}}$ \\
\hline Yield (\%) & $93.2 \pm 0.8^{\mathrm{a}}$ & $94.5 \pm 0.3^{\mathrm{a}}$ & $93.2 \pm 0.8^{\mathrm{a}}$ & $86.3 \pm 0.4^{b}$ & $84.2 \pm 0.4^{\mathrm{b}}$ \\
\hline
\end{tabular}

${ }^{1)}$ Values represent means \pm SD.

${ }^{2)}$ Values with different superscripts in the same row are significantly different at $\mathrm{p}<0.05$.

누룩에서 분리한 N4, N9 효모 및 일본 증류식 소주용 효모 인 $\mathrm{C} 4$ 의 알코올 생산량은 유사하였고, 국내 상업용 효모는 누룩분리 효모에 비해 $16.7-36.0 \%$ 낮은 것으로 확인되었다. 이러한 이유는 세 가지 원인을 먼저 생각해 볼 수 있다. 첫째는 발효기간 입국의 효소활성 저하로 쌀의 전분이 분해 되지 못하면서 알코올 생산이 낮아지는 경우이다. 발효 종 료 후 각 효모별 술덧의 당화력은 225.32-258.39 U/mL이고 a-amylase의 활성은 7.85-9.84 U/mL로 충분한 활성을 가지 고 있었기 때문에 효소활성 저하에 따른 당화불량이 원인은 아니라고 판단된다. 둘째는 발효에 충분한 효모수가 확보 되지 못한 경우이다. 술덧에 포함된 효모의 총균수는 누룩

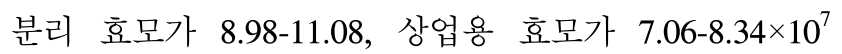
cells $/ \mathrm{mL}$ 로 통계적 유의성이 없었다. 생균수는 각각 $1.52-3.15,1.81-4.55 \times 10^{7}$ cells $/ \mathrm{mL}$ 이었으며 생존율은 각각 $28.3-39.2 \%, 23.7-64.2 \%$ 로 상업용 효모가 높았다. 발효가 정상적인 술덧에 포함된 효모수는 $10^{7}-10^{8}$ cells $/ \mathrm{mL}$ 로(45) 각 처리구별로 발효에 충분한 효모수가 확보되었기 때문에 효모 개체수에 대한 영향도 아닌 것으로 판단된다. 셋째는 효모의 당 이용률이 낮아 알코올 생산량이 떨어지는 경우이 다. 각 효모별 술덧의 환원당 함량은 각각 N9 $2.04, \mathrm{C} 42.88$ $\mathrm{N} 4$ 3.92, LP 7.92, CM $8.78 \mathrm{~g} / 100 \mathrm{~mL}$ 순으로 알코올 생산량 과 반비례하며 환원당과 알코올 함량과의 상관계수(r)가 0.997(data not shown)로 매우 높게 나타났다. 결론적으로 동일조건에서 누룩분리 효모가 상업용 효모에 비해 술덧의 당을 보다 많이 이용함으로써 알코올 생산이 증가된 것으로 이해된다.

이러한 현상은 술덧의 발효경과(Fig. 2)에서도 관찰된다. 누룩에서 분리한 $\mathrm{N} 4, \mathrm{~N} 9$ 효모는 발효 11 일에 $\mathrm{CO}_{2}$ 발생이 완만해지고 19 일에 발효가 종료되는 반면 상업용 효모는 발효 9일에 $\mathrm{CO}_{2}$ 발생이 완만해진 다음 누룩분리 효모보다 2 일 빠른 17 일에 발효가 종료되었다. 발효종료일 누적 $\mathrm{CO}_{2}$ 발생량은 N4와 N9이 각각 $418.9,452.1 \mathrm{~g} / \mathrm{mash}$ 로 상업용 효모 $\mathrm{LP}$ 와 $\mathrm{CM}$ 의 $345.3,327.6 \mathrm{~g} / \mathrm{mash}$ 에 비하여 $21.3-38.0 \%$ 높은 것으로 확인되었다. 발효가 완만해지는 시기의 누적 $\mathrm{CO}_{2}$ 생산량은 누룩분리효모가 333.0-350.5 g/mash, 국내상 업용 효모가 256.5-250.4 g/mash로 모든 $\mathrm{CO}_{2}$ 생산량이 알코 올 대사과정에서 만들어졌다고 가정하면 알코올 생산량은 각각 394.7-407.8, 268.0-261.7 g/mash로 예측할 수 있다. 이때의 술덧양은 각각 $3,926.9-3,939.5,4,001.2-4,005.0$ $\mathrm{g} / \mathrm{mash}$ 이므로 술덧의 알코올 농도는 11.2-11.8, 8.3-8.5\% $(\mathrm{v} / \mathrm{v})$ 로 계산된다.

한편, 입국의 산 함량은 건물량으로 $2.92 \%$ (Table 2)이고 쌀을 물에 넣었을 때 용적의 변화를 나타낸 원료계수가 1.15 (46)이므로 입국 $100 \mathrm{~g}$ (수분함량 $12.5 \%$ )에 물 $120 \mathrm{~mL}$ 를 


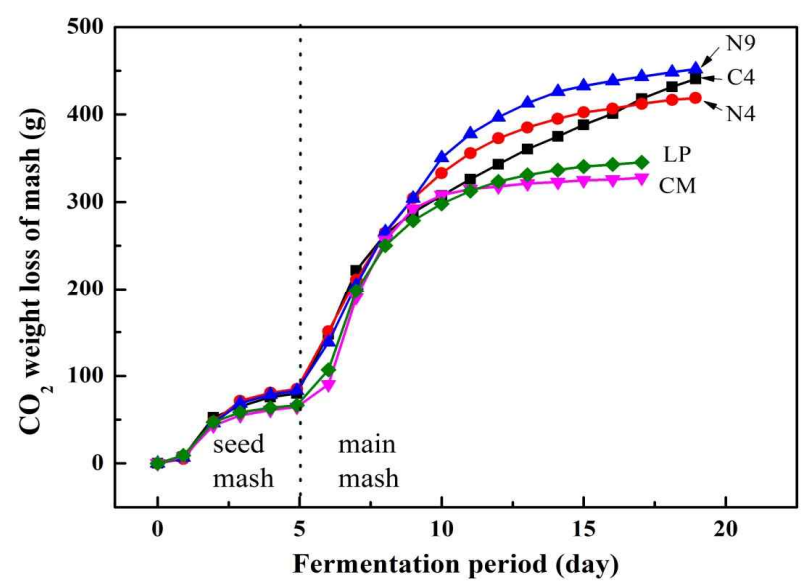

Fig. 2. Time profile of $\mathrm{CO}_{2}$ evolution during Soju brewing using isolated and industrial yeasts.

첨가하였다면 부피는 $235 \mathrm{~mL}(100 \times 1.15+120)$ 가 되며 밑술 의 산 함량은 $1.24 \%$ 가 된다. 이때 $\mathrm{pH}$ (citric acid의 $\mathrm{P}_{\mathrm{Kal}}=3.13$ ) 는 3.0-3.3 범위가 일반적이다. 이러한 환경에서 시험에 이 용된 효모는 발효에 충분한 개체수를 확보하였으나(Table 3) 국내상업용 효모는 술덧의 알코올 농도 8.3-8.5\% 부근에 서 효모 세포내로 당 흡수가 저하되면서 지속적인 발효로 이어지지 못하고 $\mathrm{CO}_{2}$ 발생량(Fig. 2)과 알코올 함량이 낮게 나타난 것으로 해석된다.

각 효모별 총당의 함량은 $3.10-9.92 \mathrm{~g} / 100 \mathrm{~mL}$ 범위로 환원 당 함량 2.04-8.78 g/100 mL를 제외하면 1.06-1.19 g/100 $\mathrm{mL}$ 의 전분이 분해되지 않은 난분해성으로 남아있는 것으 로 나타났다. 백미 사용량 등을 고려하여 계산하면 한아름 품종은 본 시험 조건에서 $4.0 \%$ 가량의 난분해성 전분을 함 유한 것으로 나타났다.

각 효모별 증류액(원주)의 알코올 함량은 41.05-41.29\% 로 유사하게 증류되었으며 증류수율은 누룩 분리균이 93.2-94.5\%, 국내상업용 효모가 86.3-84.2\%로 누룩분리 효 모로 제조한 술덧이 7.9-12.2\% 높은 것으로 조사되었다. 증류효율은 술덧에 함유된 알코올 함량에 대한 원주의 알코 올 함량비로 수율이 낮을수록 술덧에 증류되지 못한 알코올 이 많이 남아있다는 의미이다. 이로 인해 획득된 원주의 양은 누룩분리 효모가 242.23-265.55 mL이었던 반면 상업 용 효모는 173.81-193.43 mL로 25.2-52.7\%가량 낮게 나타 났다.

증류식 소주에 있어 알코올 생산량은 생산비용과 직결되 어 있기 때문에 매우 중요한 요소로 여겨진다. 동일한 쌀 양에 대해 누룩분리효모가 일반적으로 사용되고 있는 상업 용 효모보다 알코올 생산량이 최대 $36 \%$ 높게 나타났고 증류효율도 최대 $12.2 \%$ 까지 높은 결과로 원주의 생산량을 25.2-52.7\%까지 증가시켰기 때문에 제품의 생산비용을 낮 출 수 있을 것으로 기대된다.

\section{소주의 향기성분}

원주에 물을 첨가하여 $25 \%$ 로 조절한 후 1 달 동안 숙성시 킨 각 쌀 증류식 소주의 향기성분은 Table 4에 나타내었고, 주성분분석 결과는 Fig. 3 에 나타내었다.

각 효모 N4, N9, C4, LP, CM의 알코올류 성분의 합은 각각 $26.76,23.07,33.33,20.79,27.86 \times 100 \mu \mathrm{g} / \mathrm{L}$ 로 C4에서 다소 높게 나타났다. 알코류 중 butanol 및 isoamyl alcohol은 양적으로 많이 존재하고 있지만 약한 알코올 향 이외에 특별한 향이 없고 분별역치 값도 $50-600 \mathrm{mg} / \mathrm{L}$ 로 높아 관능 에는 많은 영향을 미치지 못한다(47). 반면, phenethyl alcohol은 장미향을 가지고 있으며 역치 값도 $40-70 \mathrm{mg} / \mathrm{L}$ 로 비교적 낮아 증류식 소주에서 중요한 성분이다(47). 각 소주 별 phenethyl alcohol 함량은 누룩분리 효모가 1.17-1.51×100 $\mu \mathrm{g} / \mathrm{L}$ 로 상업용 효모의 0.75-1.06보다 1.1-2.0배 높은 함량을 나타내었다.

에스테르류는 과일향, 꽃향 등의 화려한 향을 가지고 있 고 역치가 낮아 소량으로도 소주의 향기에 많은 영향을 줄 수 있는 성분이다. 각 효모별 분포를 살펴보면 양적으로 많이 함유된 성분은 ethyl acetate(과일향) 6.25-12.35, isoamyl acetate(바나나향) 4.22-16.59, ethyl caproate(사과향) 4.29-6.28, ethyl caprylate(과일향) 37.20-44.71, ethyl caprate (포도주향, 꼬냑향, 장미향) 11.55-12.08, phenylethyl acetate(장미향) $1.14-6.77 \times 100 \mathrm{\mu g} / \mathrm{L}$ 등으로 나타났다. Table 3 에서 술덧의 휘발산도가 N4 4.95, N9 6.83, C4 2.30, LP6.13, CM 5.85로 N9과 LP에서 높게 나타났다. 휘발산의 주성분 은 acetic acid로서(47) N9과 LP가 acetic acid 생산력이 높았 다고 추정되며 이들 효모로 제조된 소주에서 ethyl acetate의 함량이 다소 높았던 이유로 판단된다. Isoamyl acetate는 isoamyl alcohol이 acetyl CoA와 alcohol acetyltransferase의 작용에 의해 생성되는 성분으로서 isoamyl alcohol의 농도 에 의존적이다(48). Isoamyl alcohol의 농도가 높았던 N4와

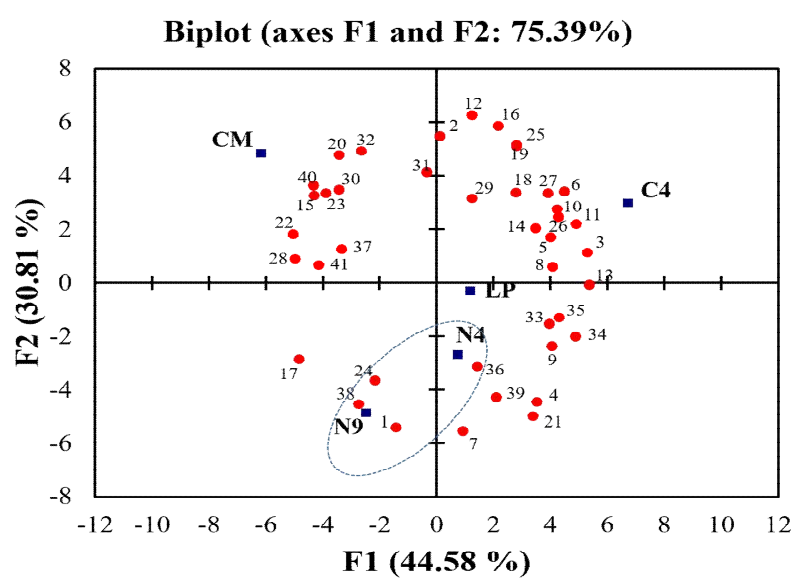

Fig. 3. Principal component analysis (PCA) of volatile compounds of Soju prepared by isolated and industrial yeasts.

The figure displays volatile compounds as numbers, and these numbers are displayed with the corresponding compounds in Table 4. 
Table 4. The peak ratio of distillated Soju (alcohol 25\%) prepared with isolated and industrial yeasts

\begin{tabular}{|c|c|c|c|c|c|c|c|}
\hline \multirow{2}{*}{ No. } & \multirow{2}{*}{ Compounds } & \multirow{2}{*}{$\begin{array}{c}\text { Retention } \\
\text { index }^{1)}\end{array}$} & \multicolumn{5}{|c|}{ Relative concentration $(\times 100 \mu \mathrm{g} / \mathrm{L})^{2)}$} \\
\hline & & & $\mathrm{N} 4$ & N9 & $\mathrm{C} 4$ & $\mathrm{CM}$ & LP \\
\hline & (Alcohol) & & & & & & \\
\hline 1 & $\mathrm{i}-\mathrm{BuOH}$ & 1099 & 4.37 & 4.63 & 3.30 & 3.64 & 4.62 \\
\hline 2 & 1-Butanol & 1152 & 0.07 & 0.06 & 0.11 & 0.12 & 0.12 \\
\hline 3 & $\mathrm{i}-\mathrm{AmOH}$ & 1234 & 20.48 & 16.98 & 26.62 & 15.72 & 21.97 \\
\hline 4 & 2-Ethyl-1-hexanol & 1474 & 0.06 & 0.07 & 0.06 & $\mathrm{ND}^{3)}$ & 0.08 \\
\hline 5 & Phenethyl alcohol & 1867 & 1.51 & 1.17 & 2.64 & 1.06 & 0.75 \\
\hline 6 & $\begin{array}{l}\text { Farnesol } \\
\text { (Ester) }\end{array}$ & 2316 & 0.27 & 0.17 & 0.62 & 0.25 & 0.31 \\
\hline 7 & Ethyl acetate & 932 & 9.28 & 12.35 & 8.66 & 6.52 & 11.17 \\
\hline 8 & Isobutyl acetate & 1015 & 0.23 & ND & 0.27 & ND & $\mathrm{ND}$ \\
\hline 9 & Ethyl butyrate & 1036 & 1.61 & 0.55 & 1.19 & ND & 1.39 \\
\hline 10 & Ethyl isovalerate & 1066 & $\mathrm{ND}$ & $\mathrm{ND}$ & 0.01 & ND & $\mathrm{ND}$ \\
\hline 11 & Isoamyl acetate & 1128 & 6.68 & 4.79 & 16.59 & 4.22 & 7.30 \\
\hline 12 & Isoamyl propionate & 1210 & 0.05 & 0.03 & 0.10 & 0.10 & 0.06 \\
\hline 13 & Ethyl caproate & 1263 & 5.39 & 4.85 & 6.28 & 4.29 & 5.60 \\
\hline 14 & Isoamyl butyrate & 1297 & 0.07 & $\mathrm{ND}$ & 0.07 & 0.03 & 0.02 \\
\hline 15 & Propyl caproate & 1341 & 0.01 & 0.01 & 0.01 & 0.02 & 0.01 \\
\hline 16 & Ethyl heptanoate & 1358 & 0.02 & 0.01 & 0.03 & 0.03 & 0.02 \\
\hline 17 & Isobutyl caproate & 1374 & 0.03 & 0.04 & 0.02 & 0.04 & 0.03 \\
\hline 18 & Ethyl caprylate & 1450 & 39.43 & 37.20 & 42.89 & 40.39 & 44.71 \\
\hline 19 & Isoamyl caproate & 1460 & 0.13 & 0.10 & 0.16 & 0.14 & 0.15 \\
\hline 20 & Propyl caprylate & 1501 & 0.03 & 0.03 & 0.04 & 0.10 & 0.06 \\
\hline 21 & Ethyl nonanoate & 1518 & 0.17 & 0.15 & 0.13 & ND & 0.15 \\
\hline 22 & Isobutyl caprylate & 1536 & 0.06 & 0.08 & 0.05 & 0.10 & 0.06 \\
\hline 23 & Ethyl methyl succinate & 1604 & 0.01 & 0.03 & 0.02 & 0.05 & 0.02 \\
\hline 24 & Ethyl caprate & 1632 & 17.53 & 15.07 & 11.55 & 13.94 & 12.08 \\
\hline 25 & Isopentyl octanoate & 1644 & 0.08 & 0.06 & 0.10 & 0.09 & 0.09 \\
\hline 26 & Diethyl succinate & 1648 & 0.33 & 0.39 & 3.64 & 0.21 & 0.21 \\
\hline 27 & Phenethyl acetate & 1783 & 2.55 & 1.14 & 6.77 & 2.32 & 1.32 \\
\hline 28 & $\begin{array}{l}\text { Ethyl laurate } \\
\text { (Aldehyde) }\end{array}$ & 1824 & 0.20 & 0.18 & 0.14 & 0.22 & 0.18 \\
\hline 29 & Nonanal & 1404 & 0.07 & 0.05 & 0.07 & 0.07 & 0.08 \\
\hline 30 & Furfural & 1448 & 0.14 & 0.22 & 0.20 & 0.27 & 0.19 \\
\hline 31 & Decanal & 1482 & 0.04 & 0.05 & 0.06 & 0.08 & 0.09 \\
\hline 32 & $\begin{array}{l}\text { 2-Nonenal } \\
\text { (Fatty acid) }\end{array}$ & 1507 & 0.04 & 0.04 & 0.04 & 0.05 & 0.04 \\
\hline 33 & Caprylic acid & 2018 & 0.15 & 0.27 & 0.32 & 0.11 & 0.23 \\
\hline 34 & Capric acid & 2229 & 1.61 & 1.14 & 1.64 & 0.72 & 1.46 \\
\hline 35 & Lauric acid & 2438 & 0.52 & 0.42 & 0.57 & 0.29 & 0.66 \\
\hline 36 & $\begin{array}{l}\text { Tetradecanoic acid } \\
\text { (Phenol) }\end{array}$ & 2634 & 0.40 & 0.42 & 0.36 & 0.31 & 0.55 \\
\hline 37 & $\begin{array}{l}\text { 4-Vinylguaiacol } \\
\text { (Ketone) }\end{array}$ & 2142 & 0.05 & 0.07 & 0.06 & 0.07 & 0.07 \\
\hline 38 & $\begin{array}{l}\text { 2-Undecanone } \\
\text { (Acetal) }\end{array}$ & 1575 & 0.07 & 0.06 & 0.01 & 0.04 & 0.05 \\
\hline 39 & Isobutanal diethyl acetal & 992 & 0.29 & 0.40 & 0.33 & 0.15 & 0.19 \\
\hline 40 & $\mathrm{PADA}^{4)}$ & 1692 & 0.25 & 0.20 & 0.15 & 0.57 & 0.28 \\
\hline 41 & Isovaleraldehyde diethyl acetal & 1075 & 0.73 & 0.73 & 0.26 & 1.13 & ND \\
\hline
\end{tabular}

${ }^{1)}$ Retention index calculated on a DB-WAX capillary column with a series of n-alkanes (C7-C33).

${ }^{2)}$ Volatile compounds were calculated with the relative peak ratio of their peak areas to that of internal standard

${ }^{3)} \mathrm{ND}$ means not detected.

${ }^{4)}$ PADA means phenyl acetaldehyde diethyl acetal. 
LP소주에서 isoamyl acetate의 함량이 높은 이유로 생각된 다. 지방산 에스테르 화합물인 ethyl caproate, ethyl caprylate, ethyl caprate는 효모별로 큰 차이를 보이지 않는 것으로 확인되었다.

에스테르 성분 중 ethyl acetate, isobutyl acetate, ethyl caproate 등의 저비점 성분은 마시기 전 술향에 기여하고 고비점 성분인 phenethyl acetate, ethyl caprylate, ethyl laurate 등은 마신 후 입안에 남는 잔향으로 작용한다(47).

각 소주에 함유된 알데히드류는 nonanal 0.05-0.08, furfural 0.14-0.19, decanal 0.04-0.09, 2-nonenal 0.04-0.05 $\times 100 \mu \mathrm{g} / \mathrm{L}$ 범위로 양적으로는 furfural의 함량이 높았다. Furfural은 탄내(49)를 가지고 있기 때문에 그 함량이 많을 경우 증류식 소주에 좋지 않은 영향을 미치게 된다. 발효과 정 중에는 거의 생성되지 않고 증류 시 술덧에 함유된 당류 가 열을 받아 아미노카르보닐 반응을 거쳐 생성된다(50). Table 3에 나타낸 바와 같이 상업용 효모인 LP와 CM효모로 제조한 술덧의 환원당 함량은 각각 $7.92,8.78 \mathrm{~g} / 100 \mathrm{~mL}$ 로 누룩분리 효모로 제조한 술덧의 함량 2.04-3.92 g/100 mL보 다 높았기 때문에 furfural의 함량도 높을 것으로 예상했으 나 큰 차이를 보이지 않았다. Pentose는 산성조건에서 가열 되면 3분자의 물이 탈수되어 furfural이 생성되지만 hexose 는 동일 조건에서 3-deoxy glucosone을 거쳐 hydroxy methyl furfural(HMF)이 되고 더욱 가열되면 levulinic acid, formic acid로 분해되는 과정에서 중간생성물로 소량 만들어 진다 (51). 이외에 증류방법 및 증류기 금속의 종류, 술덧에 함유 된 유기산 종류, $\mathrm{pH}$ 의 영향과 더불어 잔당의 종류와 양에 의해서 그 생성이 다른 것으로 알려져 있다(47). 효모별 술덧의 $\mathrm{pH}$ 및 산도는 유사하고(Table 3) 증류방법 및 증류기 의 종류는 동일하므로 술덧을 구성하고 있는 당의 종류에 많은 영향을 받을 수 있다. 술덧을 구성하고 있는 당은 원료 인 쌀의 분해 산물이며 glucose, maltose, isomaltose 및 polysaccharide가 주성분이고 pentose 성분은 쌀의 hemicellulose가 분해되어 생성된 xylose, arabinose가 소량 함유되어 있다(52,53). 누룩 분리 효모를 포함한 일반적인 효모는 xylose와 arabinose를 이용하지 못하므로(53) 술덧에 함유된 pentose양은 유사할 것으로 추측되고 furfural의 생 성에는 주로 hexose가 작용할 것으로 생각된다. 본 증류조 건인 술덧에 스팀을 주입하는 상압증류방식은 술덧의 최대 온도가 $100^{\circ} \mathrm{C}$ 를 초과하지 못하므로 각 hexose의 furfural변 환이 높지 않았기 때문에(54) 각 효모별로 furfural의 함량 차이가 적은 것으로 이해된다. 다만, 시중에 유통되고 있는 제품의 탄내는 직화방식의 증류식 소주에서 불꽃이 닫는 부분의 온도가 비교적 높기 때문에 hexose가 furfural로 많이 변환되었을 것으로 추측된다. 상업용 효모를 사용한 술덧 을 직화방식으로 증류할 경우 누룩분리 효모를 사용한 술덧 에 비해 탄내가 높을 가능성이 있다.

4-vinylguaiacol의 함량은 $0.05-0.07 \times 100 \mu \mathrm{g} / \mathrm{L}$ 로 높지 않
았으며, 효모별로도 큰 차이를 나타내지 않았다. 4-vinylguaiacol은 술덧에 함유된 ferulic acid의 일부가 증류 중 산 및 열에 의해 4-vinylguaiacol로 변환되어 유출되고 저장 중에 산화되어 바닐라향을 가지고 있는 vanillin 및 vanillic acid로 바뀌게 된다(49).

주성분 분석(Fig. 3)은 전체 분산의 $75.39 \%$ 를 설명하고 있으므로 비교적 적합한 모델로 나타났다. 전체 분산의 $44.58 \%$ 를 설명하고 있는 제 1 주성분(F1)의 각 효모별 적재 값은 $\mathrm{N} 4, \mathrm{~N} 9, \mathrm{C} 4, \mathrm{LP}, \mathrm{CM}$ 가 각각 $0.025,0.162,0.773,0.617$, 0.056 으로 일본 상업용 효모인 $\mathrm{C} 4$ 와 국내 상업용 효모인 $\mathrm{CM}$ 이 변동을 이끌었다. 전체의 $30.81 \%$ 를 설명하고 있는 제 2주성분(F2)은 $\mathrm{N} 9$ 의 적재값이 0.628 을 가지면서 다른 효모의 적재 값 0.03-0.321보다 높게 나타났다. 즉, 시험에 사용된 5종의 효모 중 $\mathrm{C} 4$ 와 $\mathrm{CM}$ 소주의 향기성분 차이가 가장 많았고 다음은 N9과 다른 4종의 효모의 분포차이가 큰 것으로 해석된다. 누룩에서 분리한 N4, N9 효모로 만든 증류식 소주가 다른 상업용 효모와 차이가 나는 성분은 1 번(i-BuOH), 38번(isobutanal diethyl acetal), 24번(ethyl caprate), 36번(tetradecanoic acid) 성분으로 나타났다.

이외에 $\mathrm{C} 4$ 소주에는 ethyl isovalerate, isoamyl acetate, diethyl succinate 등의 향기성분이 다른 소주에 비해 2.3-9.3 배 높게 나타나(Table 4, Fig. 3) C4소주의 특징을 줄 수 있는 성분으로 판단되었다. 이 중 사과향을 가지고 있는 ethyl isovalerate의 역치는 $3 \mu \mathrm{g} / \mathrm{L}(55)$ 이고 isoamyl acetate의 역치값 역시 $1.6 \mathrm{mg} / \mathrm{L}(47)$ 로 낮은 편에 속하므로 너무 과도 할 경우 전체적인 향의 균형을 깰 수 있다. $\mathrm{CM}$ 은 phenylacetaldehyde diethyl acetal과 propyl caproate 등의 성 분이 주요하게 다른 소주와 차이가 있는 것으로 나타났다 (Fig. 3). Acetal 성분은 aldehyde 성분이 알코올과 반응하여 생성되는 물질로 부드럽고 고급스러운 향을 부여하고(47), propyl caproate는 파인애플향을 가지고 있으나(56) isobutyl caprylate, ethyl laurate 등의 고비점 에스테르 성분함량 등도 높아 마시고 난 후 입안에 잔여감이 오래 머물면서 맛에 있어 좋지 않은 영향을 미칠 수 있다.

누룩분리한 효모인 N4와 N9은 알코올 생산수율을 증대 시켜 제품의 생산비용을 감소시킬 수 있으며 향기성분에 있어서도 적정한 균형을 이루고 있기 때문에 산업용으로 검토해 볼 가치가 있다고 판단된다.

\section{요 약}

재래누룩에서 분리한 효모인 N4와 N9에 대해 쌀 증류식 소주제조 특성을 살펴보았다. 원료 쌀(한아름 품종)의 일반 성분은 수분 14.7 , 조단백질 6.8 , 조지방 0.9 , 조회분 0.4 , 탄수화물 $76.5 \mathrm{~g} / 100 \mathrm{~g}$ 이었다. 제조된 입국의 총산 함량은 $2.92 \%$ (citric acid, dry base)였으며 효소활성에 있어 당화력 
은 926.72, a-amylase 52.40, gluco-amylase 887.71, a -glucosidase 0.14 , acidic carboxypeptidase 17,335.73, $\beta$ -glucosidase $174.46 \mathrm{U} / \mathrm{g}$ dry base로 나타났다. 술덧의 알코올 함량은 재래누룩 분리 효모가 $15.37-16.58 \%$ 로 상업용 효모 $12.33-13.19 \%$ 보다 $16.7-36.0 \%$ 높은 것으로 나타났다. 반면, 환원당 함량은 각각 $2.04-3.92,7.92-8.78 \mathrm{~g} / 100 \mathrm{~mL}$ 로 상업용 효모의 당 이용률이 누룩분리 효모보다 낮았다. 이러한 결 과로 증류 후 원주의 획득량이 누룩분리 효모에서 25.2-52.7\% 높았다. 쌀 증류식 소주(알코올 25\%)에서 41개 의 휘발성 성분이 검출되었으며, 주성분 분석 결과 누룩분 리 효모와 상업용 효모는 i-BuOH, isobutanal diethyl acetal, ethyl caprate, tetradecanoic acid 성분의 함량 차이가 있는 것으로 나타났다.

\section{감사의 글}

본 연구는 국립농업과학원 농업과학기술 연구개발사업 (과제번호: PJ011984)의 지원에 의해 이루어진 것입니다.

\section{References}

1. Miyazaki M (2015) History of Alcoholic Drinks. Translated by Bang WK, Jeong YK, Korea University Press, Seoul, Korea, p 52-83

2. Pae KH (1999) Literature review for transmission of the Andong Soju. MS Thesis, Andong National University, Andong, Korea, P 29-36

3. National Tax Statistics. http://stats.nts.go.kr/national/major_ detail. asp? year $=2016 \&$ catecode $=$ A06001\#. (Accessed July 2017)

4. Choi HS, Jeong ST, Kang JE, Yeo SH, Kim CW, Song GC (2016) The water of life, spirit. RDA Interrobang 168. Rural Development Administration, Jeonju, Korea, p 1-20

5. National Tax Statistics. http://stats. nts.go.kr/national/major_ detail.asp? year $=2016 \&$ catecode $=$ A06004\#. (Accessed July 2017)

6. National Tax Statistics. http://stats.nts.go.kr/ national /major_detail.asp? year $=2016 \&$ catecode $=$ A06008\#. (Accessed July 2017)

7. Irish Whiskey Association. http:// www.abfi.ie/Sectors/ ABFI/ABFI.nsf/vPagesSpirits/Home/\$File/Vision+for+I rish+Whiskey+May+2015.pdf. (Accessed July 2017)

8. Min YK, Yun HS, Jeong HS, Jang YS (1992) Changes in compositions of liquor fractions distilled from Samil-ju with various distillation conditions. Korean J Food Sci Technol, 24, 440-446

9. Park JS, Chung BW, Bae JO, Lee JH, Jung MY, Choi DS (2010) Effects of sweet potato cultivars and koji types on general properties and volatile flavor compounds in sweet potato Soju. Korean J Food Sci Technol, 42, 468-474

10. Jeong YJ, Seo JH (2012) Volatile compounds of potato Sojues produced by different distillation condition. Korean J Food Preserv, 19, 433-437

11. Lee DH, Jung JW, Lee YS, Seo JS, Park IT (2014) Fermentation characteristics for preparation of distilled liquor made of mixed grains. Korean J Food Sci Technol, 46, 446-455

12. Bae KH, Shin KS, Ryu HY, Kwon CS, Sohn HY (2007) Identification and fermentation characteristics of lactic acid bacteria isolated from the fermentation broth of Korean traditional liquor, Andong-Soju. Kor J Microbiol Biotechnol, 35, 310-315

13. Hong Y, Kim YB, Park SO, Choi EH (1997) Microflora and physiochemical characteristics of Nuruk and main mashes during fermentation of a traditional Andong Soju. Food Sci Biotechnol, 6, 297-303

14. Chung WH, Kang SH, Jung JH (1987) Microbial studies on the Korean traditional Soju-Part 1. characteristics of fungal amylases produced by the isolate from the native Youngkwang koji-. Appl Biol Chem, 30, 250-257

15. Bae KH, Ryu HY, Kwun IS, Kwon CS, Sohn HY (2007) Optimization of thickness and maturation period of Andong-Soju Nuruk for fermentation of Andong-Soju. Korean J Microbiol Biotechnol, 35, 231-237

16. Lee DS (2013) Physicochemical characteristic of distilled spirits by Nuruk type. Ph D Thesis, Seoul Venture University, Korea

17. Min SR (2014) Quality characteristics of distilled Soju with various Aspergillus species. MS Thesis, Sunchon National University, Korea

18. Choi HS, Kim EG, Kang JE, Choi JH, Yeo SH, Jeong ST (2014) Effect of varying the amount of water added on the characteristics of mash fermented using modified Nuruk for distilled-Soju production. Korean J Food Preserv, 21, 908-916

19. Hong Y, Park SO, Choi EH (1998) Quality characteristics of Andong Soju type mashes produced by the co-culture of wild microorganisms Isolated from Nuruk and mashes for Soju (Korean traditional distilled liquor). Food Sci Biotechnol, 7, 236-241 
20. Choi HS, Kim EG, Kang JE, Yeo SH, Jeong ST, Kim CW (2015) Effect of organic acids addition to fermentation on the brewing characteristics of Soju distilled from rice. Korean J Food Sci Technol, 47, 579-585

21. Ryu LH, Kim YM (2002) Esterification of alcohols with organic acids during distilled spirit distillation. Korean J Food Nutr, 15, 295-299

22. Lee YH, Eom TK, Cheong C, Cho HC, Kim IY, Lee YS, Kim MS, Yu SR, Jeong YH (2013) Quality characteristics of spirits by different distillation and filtrations. J Korean Soc Food Sci Nutr, 42, 2012-2018

23. Hong SB, Lee MN, Kim DH, Varga J, Frisvad JC, Perrone G, Gomi K, Yamada O, Machida M, Houbraken J, Samson RA (2013) Aspergillus luchuensis, an industrially important black Aspergillus in East Asia. PLoS One, 28, e63769

24. Yoshizki Y, Kin HM, Okutsu K, Ikenga M, Tamaki H, Takamine K (2015) "Nuruk", Korean traditional koji, as a possible material for producing Japanese Shochu. J Brew Soc Japan, 110, 170-178

25. Choi HS, Kang JE, Jeong ST, Kim CW, Takamine K (2015) Characterization of yeast for Soju (distilled spirits) from Korean traditional Nuruk Kor J Mycol 43, 196-199

26. Takamine K, Yoshizaki Y, Shimada S, Takaya S, Tamaki H, Ito K, Sameshima Y (2011) Estimation of the mechanism for cis and trans rose oxides formation in sweet potato Shochu. J Brew Soc Japan, 106, 50-57

27. Kirimura K, Kobayashi K, Ueda Y, Hattori T (2016) Phenotypes of gene disruptants in relation to a putative mitochondrial malate-citrate shuttle protein in citric acid-producing Aspergillus niger. Biosci Biotechnol Biochem, 80, 1737-1746

28. Okutsu K, Yoshizaki Y, Kojima M, Yoshitake K, Tamaki $\mathrm{H}$, Takamine K (2016) Effects of the cultivation period of sweet potato on the sensory quality of imo-Shochu, a Japanese traditional spirit. J Inst Brew, 122, 168-174

29. MFDS (2010) Korean Food Standards Codex. Ministry of Food and Drug Safety, Cheongwon, Korea

30. Imai Y, Tokutake S, Yamaji N, Suzuki M (1996) A new method of measuring glucose-forming activity in rice koji. J Brew Soc Japan, 91, 51-57

31. Shirokane Y, Tokutake S, Tobe K, Suzuki M (1996) Simple measurement of a-amylase activity in rice koji. J Brew Soc Japan, 91, 889-894

32. Imai Y, Tokutake S, Yamaji N, Suzuki M (1997) An improved method for measuring of a-glucosidase activity in rice koji. J Brew Soc Japan, 92, 296-302

33. Suzuki H, Imai Y, and Suzuki M (1999) A new assay for acid carboxypeptidase activity in sake koji. J Brew Soc Japan, 94, 588-592

34. Lee SS, Robinson FM, Wang HY (1981) Rapid determination of yeast viability. Biotechnol Bioeng Symp, 11, 641-649

35. NTS (2008) Official methods of analysis for alcoholic beverages. National Tax Service. Sejong, Korea, p 19-60

36. Rahayu YYS, Yoshizaki Y, Yamaguchi K, Okutsu K, Futagami T, Tamaki H, Sameshima Y, Takamine K (2017) Key volatile compounds in red koji-Shochu, a Monascus-fermented product, and their formation steps during fermentation. Food Chem, 224, 398-406

37. Park SJ, Park KW, Shin MS (2011) The cooking characteristics of high-yielding Japonica and Tongil type rice. Korean J Food Cookery Sci, 27, 35-743

38. RDA (2011) Standard food composition table, 8th revision. Rural Development Administration, Suwon, Korea, p 28

39. Narahara H (1994) Kojimold and its product koji. J Brew Soc Japan, 89, 873-881

40. Mizuma $\mathrm{T}$ (2009) Analysis of water absorption characteristics of rice for sake brewing. J Brew Soc Japan, 104, 322-330

41. Shimoda M (1988) Mugi Shochu. J Brew Soc Japan, 94, 365-371

42. Hong SB, Hong SY, Jo KH, Kim YS, Do JH, Do JY, Noh SB, Yoon HH, Chung SH (2015) Taxonomic characterization and safety of Nuruk molds used industrially in Korea. Kor J Mycol, 43, 149 - 157

43. Iwano K, Fukuda K, Mikami S, Shinok S (1989) Difference in enzyme production by Shochu koji made with various commercial Shochu seed-koji. J Brew Soc Japan, 84, 179-182

44. Iwami A, Kajiwara Y, Takashita H, Omori T (2005) Effect of the variety of barley and pearling rate on the quality of Shochu koji. J Inst Brew, 111, $309-315$

45. Lewis MJ, Young, TW (2012) Brewing (second edition). Springer Science \& Business Media. New York, USA, p 279-293

46. Bae SM (2003) Korean distilled beverage (Soju) brewing technology. Bae Sang Myun Brewery Institute, Seoul, Korea, p 115

47. Lee JK, Moon SH, Bae KH, Kim JH, Choi HS, Kim TW, Jeong C (2016) Distilled spirits. Kwangmoonkag Co, Paju, Korea, p 367-485 
48. Yoshimoto H, Fukushige T, Yonezawa T, Sone H (2002) Genetic and physiological analysis of branched-chain alcohols and isoamyl acetate production in Saccharomyces cerevisiae. Appl Microbiol Biotechnol, 59, 501-508

49. Kanauchi M (2012) Characteristics and Role of Feruloyl esterase from Aspergillus awamori in Japanese Spirits, 'Awamori' Production. In: Scientific, Health and Social Aspects of the Food Industry, Valdez B (Editor), InTech Co, Rijeka, Croatia, p 145-162

50. Nakama A, Kim EH, Shinohara K, Omura H (1993) Formation of furfural derivatives in amino-carbonyl reaction. Biosci Biotech Biochem, 57, 1757-1759

51. Holme HK, Lindmo K, Kristiansen A, Smidsrod O (2003) Thermal depolymerization of alginate in the solid state. Carbohydr Polym, 54, 431-438

52. Goto R, Thomas BR, Rodriguez RL, Kajiwara Y, Takashita H, Omori T (2002) Analysis of saccharides in barley Shochu mash using a fluorophore-assisted carbohydrate electrophoresis method. J Brew Soc Japan, 97, 143-149
53. Soga T, Serwe M (2000) Determination of carbohydrates in food samples by capillary electrophoresis with indirect UV detection. Food Chem, 69, 339-344

54. Ameur LA, Mathieu O, Lalanne V, Trystram G, Birlouez-Aragon I (2007) Comparison of the effects of sucrose and hexose on furfural formation and browning in cookies baked at different temperatures. Food Chem, $101,1407-1416$

55. Ferreira V, Lopez R, Cacho JF (2000) Quantitative determination of the odorants of young red wines from different grape varieties. J Sci Food Agric, 80, 1659-1667

56. Chin ST, Nazimah SAH, Quek SY, Man YBC, Rahman RA, Hashim DM (2007) Analysis of volatile compounds from Malaysian durians (Durio zibethinus) using headspace SPME coupled to fast GC-MS. J Food Compos Anal, 20, 31-44 